\title{
Partnership of the Village Head, Village Consultative Body and Customary Institutions \\ Tim Kerja PSP2M
}

\begin{abstract}
The Government of Kayeli village is an integral part of the District government Buru where the administrative elements make the Kayeli village government have to run the administrative tasks strictly in their activities, in fact A involvement in traditional institutions that eventually affect the orientation and implementation of development. The three elements of village institutions namely village Governments, village consultative bodies and indigenous institutions are able to collaborate from planning to monitoring the development of the Kayeli village community. This research is a qualitative study aimed at describing the partnerships that awakened between institutions in the village of Kayeli. The research site is focused on Kayeli village. The number of informant interviews of 30 people consisting of village apparatus, public figures, indigenous people and local communities is taken purposive. The analytical techniques used to follow the concepts given by Miles and Huberman include data reduction, data presentation and withdrawal of conclusions. The results showed that the relationship that awakened from these three institutions was able to create harmonization of village development that materialized through the planning, implementation and supervision conducted jointly with Communication and active role in village development.
\end{abstract}

Keywords: Village, Partnership, Community, Culture, Development, Kayeli

\section{INTRODUCTION}

Village government is the smallest government of local governance, government that directly relates to the village community. The measure of the success of village government is determined by the performance of the village government, village head and the village consultative agency including the customary institution as the primary instrument of a government in the village, then the element of synergy between institutions become Key drivers in Village development.

The village of Kayeli is one of the indigenous villages in the Buru regency which still shows the synergy between institutions in the village where the village head and the village consultative Agency are granted the right to govern the community through the agreed village regulations With the villagers while the customary institutions are given the authority to participate in the development planning and supervise the social development of village society culture. The village is a form of government system that is highly decentralized and autonomous so that the central government also respects the autonomy that is owned by the village as the unity of the legal community that has an original structure based on the privileges Village owned, one of which is able to perform legal acts of both public law and civil law[1], has wealth, property and can be prosecuted and demanded in advance of the court[2].

The village chief is the country's highest government unit responsible for the welfare of the villagers[3], so that the effectiveness of the village head determines that the village is advancing. It is also necessary for supervisors to supervise the performance of the Government of the head of the village called the village's consultative body or often called BPD[4]. With the BPD, it will be achieved balance of village governance performance. Besides the supervision function of BPD also functions in the container and the supplier of village community aspirations and legislation function that is instrumental in the making of village regulation together with the village head, where the village regulation will then reported to the regent.

Beautiful Maulidiyah in the research conducted in the year 2014 in West Lampung presents about the position and participation of indigenous institutions in the formation of the second rules in the Pekon way Empulau Ulu, the Adat Institute in Pekon Way Empulau Ulu has a position The reorganization of the economy. Although the Adat institution has a position that is outside the arrangement of the government organization of Pekon, but the role of the adat institution in the formation of the Pekon regulation is only as structural and functionally the position of customary institutions still lacking Optimal communication and interaction between the Government and the Pekon community[5].

Furthermore, the development of the village can be interpreted as an interaction between the institutions in every action to achieve a change, theoretically the intended interaction is suspected to produce five possible changes. Firstly, integration is the incorporation of the laws of the country, local laws and other similar laws; Secondly, the incorporation is to adopt some of the laws of the country into local law or vice versa; Third, conflicts are the laws of the state and the local laws referred to each other; Fourth, the competition is the laws of the country, local laws and other laws run on their own in accessing natural resources; Fifth, avoidance is one of the laws that exist avoiding the enforceability of the other law[6]. These possibilities may happen when each legal system organizes the same objects with different perspectives. Therefore, the necessary harmonization of the interfacing legal systems becomes integrated and harmonious. Convergence of settings against the same object will make setting more effective and efficient.

\section{LITERATURE REVIEW}

\subsection{Village Governance Structures}

At the very essence of village governance in Indonesia is carried out by two main elements, namely village government institutions and the village consultative Agency, the village government elements function to conduct government policies on the upper level and Policies through consultation at the village level [6]. While the BPD serves to establish various village regulations set together with the village head, as well as to accommodate and distribute the aspirations of local villagers, which have been inventoried, formulated and delivered by village governments To BPD[7]. 
The relationship between the two elements of the village government's governance which in this case the working relationship between the BPD and the village government is partnership, as Wasistiono and Tahir stated that in an effort to reach the goal of the welfare Village People's lives, each element is the village government and the village consultative Agency can perform its function by gaining support from other elements[8]. In the implementation of village governance in Indonesia has its own principle that should be considered in the implementation, the principle of governance of the village is in accordance with the substance, philosophical and spirit of the Village Act. The principle of village government administration is governed by article 3 of the Law No. 6 of 2014, which reads; Village arrangement based on recognition, subsisity, diversity, togetherness, solidarity, family, deliberation, democracy, independence, participation, equality, empowerment and sustainability[9].

In addition to observing the principle of arrangement about the village according to Rahyunir and Maulidiah that the administration of village government should observe the basic implementation of village governance, as stated in section 24 of Law No. 6 of 2014, namely; Principles of legal certainty, orderly governance, orderly public interest, openness, proportionality, professionalism, accountability, effectiveness and efficiency, local wisdom, diversity and participatory[10]. One of the purposes of organizing and managing the governance of the village is to provide recognition and respect for the existence of the village itself in the government system of the unitary Republic of Indonesia so that the government and village community Manage the village freely. In this law, the existence of the village can be domiciled in the city other than domiciled in the district as it happened so far. Village status pursuant to article 5 of Law No. 6 of 2014, ie; Village domiciled in district area[11]. In the implementation of the village will also be able to domiciled in the city government, so far the village only domiciled in the district only, so that usually the villages in the city has changed its status into the Government of the village, based on Development of the Government and the village community itself.

The existence of local culture in the life of the village, expressed by Effendy that a local culture or a local wisdom is a dimension that is the identity of the local people in elaborating common life including accessing Horizons of knowledge from the outside world. Therefore in national and state life and in local, regional, and global associations, the traits of local culture are regional is not something that can reduce unity and perestness in the Reformation era and Globalization is now, as the saying goes global thinking local act.

\subsection{Indigenous Institutions}

According to the provincial regulations of Maluku province about the preservation of culture, indigenous institutions, namely the community organizations that because the historical or origin of its origins glorify customary law and encourage its members to conduct conservation activities and cultural custom development. The definition of Adat institution according to regulation of the Minister of Domestic affairs No. 5 of 2007 about the guidelines for Community arrangement, indigenous institutions is a public institution both deliberately formed and which reasonably has grown and developed in In the history of society or in a specific public or customary law with the jurisdiction and the rights to property in the customary law, as well as the right and authority to govern, manage and resolve the various issues of life In relation to and in reference to applicable customs and customary laws[12].

Adat Institute has the duties and obligations of (1) to be a facilitator and mediator in the resolution of disputes concerning customs and customs of society. (2) Empowering, developing, and preserving the customs and customs of the community in order to enrich the culture of the region as an integral part of national culture. (3) To create a relationship that is democratic and harmonious and objective between the head of Adat, the indigenous peoples, indigenous leaders with government officials at all levels of government in the district customary districts. (4) To assist the smooth of government wheels, implementation of development and/or property of Adat institution with a fixed attention to the interests of local customary law community. (5) Maintain a healthy and dynamic national stability that can provide extensive opportunities to the government officials, especially the village government in the implementation of higher quality development and the development of a fair and democratic society. (6) Creating an atmosphere that can guarantee the preservation of indigenous peoples ' destruction in order to strengthen the unity and unity of the nation. (7) To foster and preserve the culture and customs and the relationship between indigenous peoples and the Government of the village and Lurah. (8) to mengayau the customs. (9) Giving suggestions and opinions to various individuals, groups/institutions and Governments on indigenous issues. (10) Implementing the decisions of the Paruman with the rules set forth. (11) Conducting thorough customs counseling[13].

The customary institution with its authoritative authority must be empowered wisely given the local wisdom. Community development in the village required a touch of modern management related to the management of resources, particularly supporting resources, both human resources, funding resources/finance, resource management technology and information.

\subsection{Partnership}

According to Anwar Economic development with a partnership pattern can be considered as the most profitable business is mainly reviewed from the achievement of long-term development goals. Dictionary of Bahasa Indonesia sees partnerships as a partnership of business cooperation for the purpose of obtaining profit[14]. Unlike Muhammad Jafar Hafsah and Ian Linton who viewed the partnership as a business strategy conducted by two or more parties in the principle of requiring each other and raising each other[15]. The partnership system rests on trust, with its among others (a) more equitable equations and organizations, (b) a supple, flexible actualization hierarchy (c) of natural-based spirituality, (d) The low level of chaos that forms in System (E) gender Equality and justice[16].

At first there is often a disharmony between the village government and the BPD because (a) the way of understanding the rules 
are less thorough and less good (b) many occur disciplinary to the order made by themselves (c) Misunderstanding of their rights and obligations.

Further developments were seen that the village government and BPD relations became better[17] for some reason (a) began to grow awareness, the notion of their rights and obligations (b) The BPD has been involved from the beginning-to the end of each Activities involving Community duty and development (c) they realize that partners are filling, understanding and solving problems together.

The three important principles in partnership[18], namely (1) the equality or balance of its approach is not top down or bottom up, not also on the basis of mere power, but mutual respect, respect and mutual trust. To avoid antagonism it is necessary to build mutual trust. Equality includes awards, obligations, and bonds[19]. (2) transparency[20]. Transparency is needed to avoid mutual suspicion between working partners. Includes transparency of information management and transparency of financial management. (3). Mutually beneficial. A partnership must bring benefits to all parties involved.

\section{Method}

This research was conducted in Kayeli village, Buru Regency. The determination of the research site is conducted purposive[21] with the consideration that Kayeli village was chosen as the location of research because it has unique characteristics of the influence of Adat institution in village governance structure. The number of informant as many as 30 persons taken purposive[22] in consideration of the informant is considered as the stakeholder to achieve the research objectives[23]. Informan is a village apparatus, a religious figure, a customary figure as well as a society that lives in research sites. The data on this research is derived from primary data sources and secondary data, with data collection techniques used through observations, interviews, questionnaires and library studies[24]. In the interview step, researchers conducted a thorough interview with the informant[25] as well as the direct observation of all activities undertaken by the informant. Researchers are also looking for additional information related to the government activities of Kayeli village[26]. The interview was conducted at 17.00-22.00 where the researchers adjusted the working time and the entire informant. The analytical techniques used in this study are qualitative data analysis following the proposed concepts of Miles and Huberman and Spradley[27]. Miles and Huberman, suggests that activities in the analysis of qualitative data are conducted interactively and sustainably continuously at every stage of research so that it can be completed and data until saturated. Activity in data analysis is data reduction, data presentation, drawing conclusions.

\section{RESULT}

\subsection{General Conditions Kayeli Village}

The Government of Kayeli village is an integral part of the district government of Buru, in the implementation of a very interesting pattern of synergity that is the involvement of adat institutions in every decision making and supervision to Village development. Formal institutional is represented by the village government and the BPD but the existence of Adat Institute makes the pattern of governance of Kayeli village into a government system that has the ability to share duties and authorities as described in the table Following.

From table 1 above, the function and position of each institution in Kayeli village. Basically, the institutional structure in the village of Kayeli represented by the village chief has the right to propose government organizational structures and the work in the village to increase Kayeli Villages is a village rich in customs so the role of institutions Customs is crucial in running the government wheel.

Institutional activities of government in development affairs become easy in the implementation when each institutional in the village is able to synergize the skills they have to plan or perform Village development activities Kayeli.

From table 2 above, it appears that the institutional activities between the village head, BPD and Kayeli customary institutions correspond to the mapping of each institution. Village chief besides running the government wheel as the head of village, he also able to develop economic business for the benefit of society and also facilitate the community with a sustainable development orientation.

Sustainability of development can be seen through the roles taken by each institution where sustainability is seen from the synchronization of planning and execution as presented in table 3.

Rom the table above image that the head of village Kayeli, organizing the tasks of the general Government, create a working program with reference to the Government's work program, formulate village government policy, formulate and establish General Service policies in the village environment, establishing technical guidance procedures for the smooth execution of government duties, development and community, to conduct the development of organizational administration and governance and Provide administrative technical services to the entire staff.

Meanwhile, the village consultative Agency, establishing the village regulation with the head of village and indigenous 
institutions, accommodating and channeling community aspirations; Discussing the draft village regulation with the head of village and indigenous institutions implementing supervision over the implementation of village regulations and village head Regulation, proposes the appointment and termination of village head, forming coaching and training Local resource management, digging, accommodating, collecting, formulating and channeling community aspirations. While the customary institution of the village function in the village, the establishment of Kayeli, the development of traditional Arts group that able to introduce culture in Kayeli village.

\subsection{Cooperation in Village Development}

Cooperation of village apparatus in organizing village government is one indicator to see the performance of village apparatus. In this case the apparatus to cooperate with others in order to accomplish the tasks that have been determined so that the results of the work will be better. Village apparatus knows that cooperation is essentially showing an agreement between 2 (two) people or more mutually beneficial by providing information directly to the apparatus that we want to invite or that is needed Help to cooperate in a job, such as office administration, service to the community, Village development, and other matters aimed at improving apparatus performance, then mutual deliberation between the apparatus in the Office Kayeli Village.

Thus to complete the work of each village apparatus must cooperate with the colleagues who are expected to be able to help finish the work charged to him, where the apparatus collaborate With co-workers in one job so that the work can be completed just in time.

\section{Discussion}

Partnership between institutions in a planning and implementation of development is necessary for the achievement of maximum results [20]. The existence of government institutions and customary institutions become two important factors in the realization of development[28]. The mandate of the law has been to construct a government agency in the smallest scale into a rigid and full of limitations as a result of the structure of a very structural thought line while the customary institution becomes an expression and Freedom of the local community in understanding its own needs[29].

Institutionally the three institutions have a fairly clear limitation in which the function of the mandated according to the regulation of village institutions has administrative function, representatives institution has a function of legislation while customary institutions are listed as Non-governmental organizations[30][31]. In fact, the third involvement of the institution was followed by the division of work and the authority to make the limit is increasingly erased in the process of building Kayeli village.

Institutional activity is a concrete proof that the implementation of development is not dominated by the village government [32], but it is realized through the division of roles and functions that are mutually supportive. The realization of cooperation in processing the development is clear that the main role is conducted based on the decision through the mechanism of meeting and deliberation without leaving each other institution so that the communication that awakens into the main capital In conducting institutional activities.

The roles of these three institutions have an impact on planning, implementation and supervision[33]. Development planning carried out jointly will lead to openness and able to minimize horizontal conflicts between society and institutional. The trust built since the beginning becomes a large capital for a complete development achievement[34]. The implementation is done jointly into activities that are able to bear a sense of responsibility and sympathy that what is done is the result of cooperation for the sake of the whole village community, while supervision becomes very It is important to maintain trust between the planner and the executor of development and encourage community confidence to increase development participation[35].

The most important Factor of institutional and interinstitutional is communication. The communication built in reciprocal makes each institution understand what to do so that there is no jealousy or suspicion that causes disharmony in the implementation of Village development.

A partnership that awakens between the village government, the village's consultative body and the Adat institution harmonizes from the formal and informal elements so that the construction of the Kayeli village is able to achieve the ideal situation for community welfare achievement.

\section{Conclusion}

Partnership of institutions becomes the main capital in the development of rural communities where trust, existence and cooperation become a key pillar in encouraging community development. Administrative limitations are not a problem when there is an intense inter-agency communication so that trust can be a capital in planning, implementation to the supervision of village development. The flexible distribution of roles and authorities will create an increasingly easy institutional situation to adjust the working orientation to support sustainable village development achievement. Communication is an important instrument to safeguard and minimize the emergence of conflict between institutions in each development process. 


\section{REFERENCES}

[1] M. C. B. Umanailo, "Kalesang Dorp in Context De Bouw van Village," 2019, pp. 1-7.

[2] M. C. B. Umanailo, ILMU SOSIAL BUDAYA DASAR, 1st ed. Namlea: FAM PUBLISHING, 2015.

[3] A. Wael et al., "' Bupolo' Motion Reading," Int. J. Sci. Technol. Res., vol. 8, no. 9, pp. 2154-2158, 2019.

[4] M. C. B. Umanailo, "Desa Sebagai Poros Pembangunan Daerah," 2015.

[5] B. Sam et al., "Female Feminism in the Customary Island of Buru," Int. J. Sci. Technol. Res., vol. 8, no. 8, pp. 1877-1880, 2019.

[6] M. C. B. Umanailo et al., "Comprehension To Village," 2018, pp. 1-2.

[7] A. L. Wabula, M. Musyawir, A. Irmawati, B. Rebel, D. M. Darajat, and M. C. B. Umanailo, "Maghrib Movement," Int. J. Sci. Technol. Res., vol. 8, no. 9, pp. 2134-2138, 2019.

[8] M. C. B. Umanailo, MASYARAKAT BURU DALAM PERSPEKTIF KONTEMPORER, vol. 53, no. 9. 2015.

[9] L. J. Buton et al., "The Effect of Nasa Liquid Organic Fertilizer Concentration and Planting Distance to Growth and Production of Beans," Int. J. Sci. Technol. Res., vol. 8, no. 9, pp. 2144-2147, 2019.

[10] M. C. B. Umanailo, "Teknik praktis grounded theory dalam penelitian kualitatif," 2018, no. April, p. 127.

[11] M. C. B. Umanailo, "Overview of Phenomenological Research," 2019, pp. 1-6.

[12] M. C. B. Umanailo, N. Handayani, A. Masniati, S. H. Makatita, and S. Lisaholit, "The Urbanization and Diversification of Farmland Namlea Village," Int. J. Sci. Technol. Res., vol. 8, no. 8, pp. 1049-1053, 2019.

[13] S. Yusuf, M. C. B. Umanailo, R. N. Putri, D. Qhuril, M. Ely, and D. Darma, "Village Institution Relations in the Utilization of Village Funds in Namlea District," Int. J. Sci. Technol. Res., vol. 8, no. 8, pp. 1837-1842, 2019.

[14] M. C. B. Umanailo, "Studi pada Masyarakat Desa Waimangit Kabupaten Buru," SOCA, vol. 12, no. 12, pp. 63-74, 2018.

[15] M. C. B. Umanailo, "EKSISTENSI WARANGGANA DALAM RITUAL TAYUB."

[16] B. S. Amanto, M. C. B. Umanailo, R. S. Wulandari, T. Taufik, and S. Susiati, "Local Consumption Diversification," Int. J. Sci. Technol. Res., vol. 8, no. 8, pp. 1865-1869, 2019.

[17] M. C. B. Umanailo, Sosiologi Hukum, 1st ed. Namlea: FAM PUBLISHING, 2016.

[18] M. C. B. Umanailo, "Keterbatasan penggunaan teknologi informasi pada pelayanan dan pembelajaran di universitas iqra buru," 2016.

[19] M. C. B. Umanailo, "Integration of Community Empowerment Models [Pengintegrasian Model Pemberdayaan Masyarakat]," Proceeding Community Dev., vol. 2, p. 268, Mar. 2019.

[20] M. C. B. Umanailo, "Discourse on the Consumerist Community Consumption," J. Soc. Sci. Res., vol. 5, no. 54, pp. 1181-1186, Apr. 2019.

[21] A. Hasan Afandi and M. C. B. Umanailo, "Watudakon Citizens 'Social Conflict on Joker Toll Road Development in 2017 in Kesamben District, Jombang Regency," J. Soc. Sci. Res., vol. Special Is, no. 5, pp. 656-661, 2018.

[22] S. S. F. Assagaf et al., "Construction of the Village as a Development Shaft in the Island Buru," Int. J. Sci. Technol. Res., vol. 8, no. 9, pp. 2139-2143, 2019.

[23] L. Rumkel, B. Sam, and M. C. B. Umanailo, "Village Head Partnership, Village Consultative Body and Customary Institution in Village Development," Int. J. Sci. Technol. Res., vol. 8, no. 8, pp. 1058-1063, 2019.

[24] M. C. B. Umanailo, R. Umanailo, R. Bugis, and A. T. Bon, "Empowerment Community in Buru Regency," in Proceedings of the International Conference on Industrial Engineering and Operations Management, 2019, pp. 2070-2075.

[25] M. C. B. Umanailo, I. Hamid, M. Nawawi, S. Pulhehe, S. Yusuf, and A. T. Bon, "Utilization of Qualitative Methods in Research Universities," in Proceedings of the International Conference on Industrial Engineering and Operations Management, 2019, pp. 2076-2081.

[26] M. C. B. Umanailo et al., "Cybercrime Case as Impact Development of Communication Technology That Troubling Society," Int. J. Sci. Technol. Res., vol. 8, no. 9, pp. 1224-1228, 2019.

[27] M. C. B. Umanailo and T. Yatno, Kajian dan Analisis Sosiologi Dalam Bentuk Kumpulan Essay, Makalah dan Opini. 2015.

[28] H. Hamiru et al., "Eucalyptus Oil Workers," Int. J. Sci. Technol. Res., vol. 8, no. 9, pp. 1817-1820, 2019.

[29] M. C. B. Umanailo, Marginalisasi Buruh Tani Akibat Alih Fungsi Lahan. 2016.

[30] M. C. B. Umanailo, "recycling' consumerism to construction of modern society," no. 1904, 1964.

[31] W. Malmia et al., "Problem-Based Learning as an Effort to Improve Student Learning Outcomes," Int. J. Sci. Technol. Res., vol. 8, no. 9, pp. 1140-1143, 2019.

[32] M. C. B. Umanailo et al., "Dominance of Economic Capital in Political," in Community Development, Decentralization \& Local Autonomy Politic \& Democracy, Fisip Universitas Brawijaya, 2018, pp. 1-120.

[33] M. C. B. Umanailo, M. Yulisvestra, K. K. Oki, W. Mulyasari, and R. Ridwan, "The Thought of Emile Durkheim in the Contestation of Development in Indonesia," Int. J. Sci. Technol. Res., vol. 8, no. 8, pp. 1881-1885, 2019.

[34] M. C. B. Umanailo, MASYARAKAT BURU DALAM PERSPEKTIF KONTEMPORER (Kajian Kritis Perubahan Sosial di Kabupaten Buru), vol. 1. Namlea, 2017.

[35] R. Bugis et al., "Workers in the Namlea Market," Int. J. Sci. Technol. Res., vol. 8, no. 9, pp. 2044-2047, 2019. 